\title{
Rocky reef fish community structure in two Azorean islands (Portugal) central North Atlantic
}

\author{
ÁTHILA ANDRADE BERTONCINI ${ }^{1}$, LEONARDO FRANCISCO MACHADO ${ }^{2}$, JOÃO PEDRO BARREIROS ${ }^{2}$, \\ MAURÍCIO HOSTIM-SILVA ${ }^{3}$ AND JOSÉ ROBERTO VERANI ${ }^{1}$ \\ ${ }^{1}$ Universidade Federal de São Carlos-PPGERN_CxP.676 São Carlos SP 13.565-905 Brazil, ${ }^{2}$ Universidade dos Açores, \\ Departamento Ciências Agrárias and ImarAçores 9701-851 Angra do Heroísmo, Portugal, ${ }^{3}$ Centro Universitário Norte do Espírito \\ Santo-CEUNES-UFES-Rodovia BR 101 Norte, Km. 6o, Bairro Litorâneo, São Mateus-ES 29.932-540 Brazil
}

\begin{abstract}
The community structure of shallow rocky reef fish fauna of the Azores Archipelago is described from underwater visual censuses carried out at eight areas (Terceira and Corvo Islands). A total of 52 fish species from 26 different families was observed, and the ten most abundant fish corresponded to $82.7 \%$ of all fish. Trophic categories are given for observed species with comments on distribution and densities along sampled depth strata. Mean densities along sampled strata were tested for significant differences. Sparidae, Labridae and Carangidae were the most speciose families being Diplodus sargus, Pagellus acarne, Coris julis, Thalassoma pavo and Tripterygion delaisi the most abundant species that consequently also accounted for the highest densities.
\end{abstract}

Keywords: shallow rocky reefs, fish communities, trophic structure, temperate reefs, Azores

Submitted 3 September 2009; accepted 2 December 2009

\section{INTRDDUCTION}

The Archipelago of the Azores (Figure 1), the most isolated islands in the North Atlantic, is composed of nine volcanic islands, geologically recent, located close to the Mid-Atlantic Ridge (França et al., 2003) and spread over $600 \mathrm{~km}$ separated from the nearest continental coasts by at least $1300 \mathrm{~km}$ (Morton et al., 1998), forming the Macaronesian archipelagos with Madeira, the Canary and Cape Verde Islands.

Terceira Island is one of the five islands that form the central group of the Azores, being also the third largest $\left(385 \mathrm{~km}^{2}\right)$. With $29 \mathrm{~km}$ of length and $18 \mathrm{~km}$ width, it is located $150 \mathrm{~km}$ from São Miguel Island (where the Azores' capital, Ponta Delgada is located) and $55 \mathrm{~km}$ from São Jorge Island.

Corvo (COR) is the smallest island in the archipelago, located on the North American Plate along the Mid-Atlantic Ridge between the European and the American Plates. With only $17 \mathrm{~km}^{2}$, semi-circular form, $6.5 \mathrm{~km}$ long by $4 \mathrm{~km}$ wide, it is the most isolated island in Europe and along with the island of Flores forms the Occidental group.

The Azorean ichthyofauna started to be studied in the scientific expeditions to the Archipelago, especially at the end of the 19th Century, but up to the 1980 os research basically produced species checklists and taxonomic reviews (Afonso, 2002).

During the last two decades, the Archipelago has received significant contributions to the shore fish studies, on biology

Corresponding author:

A.A. Bertoncini

Email: athilapeixe@gmail.com (e.g. Nash \& Santos, 1993; Barreiros, 1995; Santos et al., 1997; Morato et al., 2000, 2001; Sousa et al., 2003), behaviour ecology (e.g. Santos, 1995; Barreiros \& Santos, 1998; Azevedo et al., 1999; Barreiros et al., 2002, 2008; Soares et al., 2002; Figueiredo et al., 2005; Bertoncini et al., 2009), habitat use (Afonso et al., 2009), community ecology (Ré, 1990; Patzner et al., 1992; Patzner \& Santos, 1993; Azevedo, 1997; Porteiro et al., 1996, 1998; Harmelin-Vivien et al., 2001; Afonso, 2002, 2007) and intertidal ecology (e.g. Santos et al., 1994; Azevedo et al., 1995). These studies represent a reasonable knowledge on Azorean fish communities regarding their qualitative composition, biogeographical affinities and seasonal variations.

Shallow rocky reef fish communities in the Azores, investigated by Afonso (2002) are known to be influenced by geographical variables (different degrees of oceanographic regimes) and depths, where irregular substrates seemed to promote greater abundance and habitats can be characterized mainly by a mixture of species typical of pelagic offshore habitats with species typical of coastal habitats, and high abundances of small pelagic and predator species.

Despite major oceanographic current flow from west to east, the Azorean marine ichthyofauna fauna has stronger biogeographical affinities with the eastern Atlantic than the western Atlantic mainly with the archipelagos of Madeira and the Canaries, and to a lesser extent with continental coasts of north-west Africa, Southern Europe, and the Mediterranean (Santos et al., 1995).

In the present study, we give an annotated list of the shallow coastal fish communities of the Azores Archipelago, analysing community structure parameters, trophic structure, and with comments on their abundances at distinct areas and depths. 


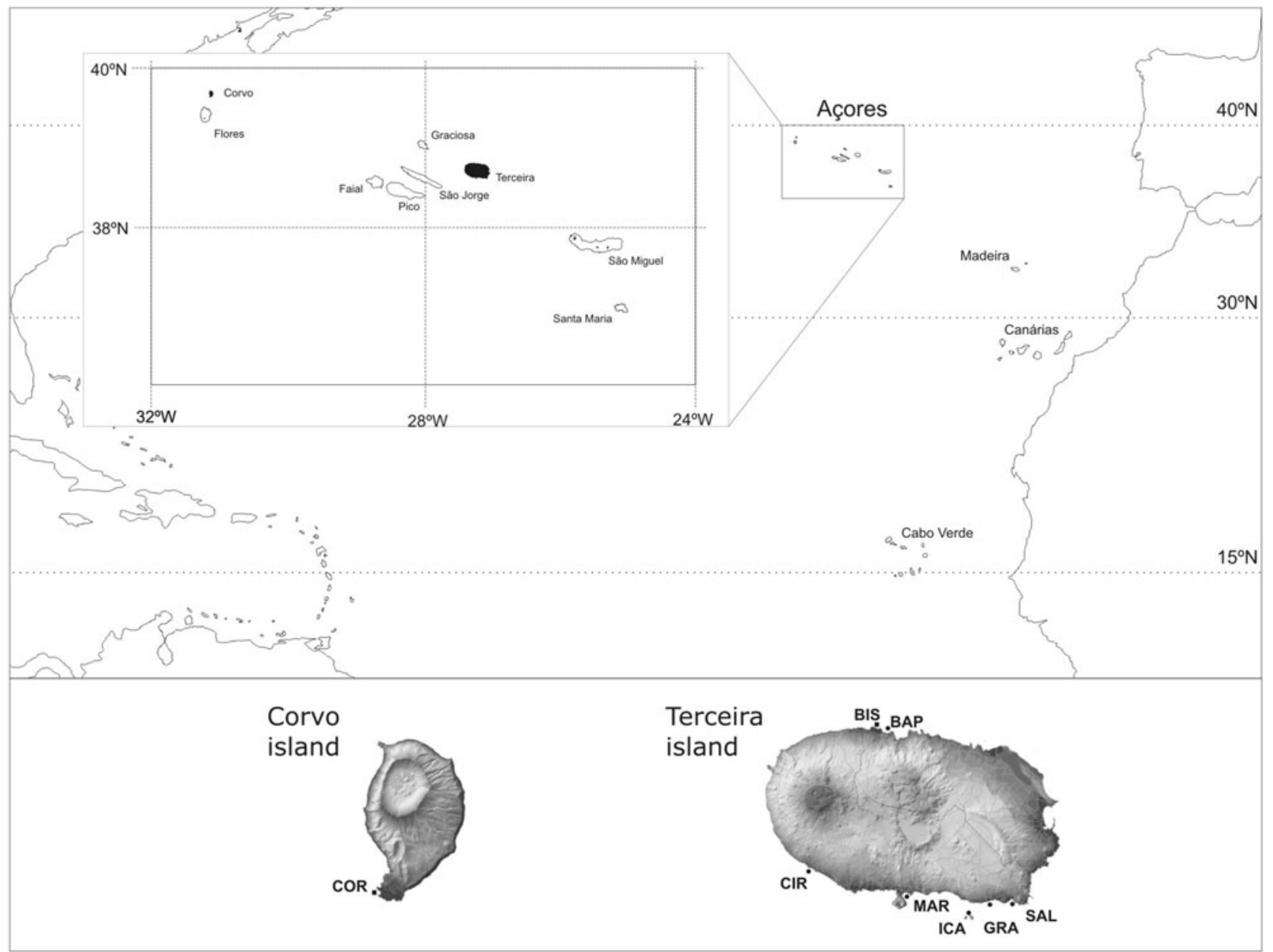

Fig. 1. Azores Archipelago. Sampled islands in detail: Terceira and Corvo with respective sampled sites: Shallow tide pools: COR, Corvo, BIS, Biscoitos; rocky reef shores: BAP; Baía das Pombas; CIR, Cinco Ribeiras; MAR, Marina; ICA, Ilhéu das Cabras; GRA, Gruta das Agulhas; SAL, Salgueiros.

\section{MATERIALS AND METHODS}

Surveys were conducted from June to October 2007. Eight areas were considered in this study (Figure 1): one shallow open tidal pool at Corvo Island; another shallow open tidal pool, five rocky shores and one rocky bottom within a marina at Terceira Island. Samples covered four depth strata according to the rocky shore characteristics (2, 6, 9 and $14 \mathrm{~m})$.

The reef fish community was assessed through $40 \mathrm{~m}^{2}$ $(20 \mathrm{~m} \times 2 \mathrm{~m})$ underwater strip transects, adapted from Brock (1954). Divers swam $20 \mathrm{~m}$ one way for $5-7$ minutes along each transect, identifying and recording the number and size of each highly mobile fish species observed within a distance of $1 \mathrm{~m}$ on each side of the transect, and returned during 5-7 minutes accounting only for the cryptic species, reducing the underestimation of this fish group count. Fish sizes were estimated according to four size-classes $(<10 \mathrm{~cm}$, $11-20 \mathrm{~cm}, 21-30 \mathrm{~cm}$ and $>31 \mathrm{~cm}$ ) and written on PVC slates; being the total fish abundance of a species and the sum of size-classes abundances. Sampling methodology and divers remained the same during the whole period to minimize biases inherent in Underwater Visual Census (UVC) (Kulbicki, 1998; Edgar et al., 2004).

Variations in the composition and structure of the community were investigated using mean densities (fish $/ \mathrm{m}^{2}$ ) (Magurran, 2004). The dominance-diversity curves of all eight sampling areas, based on the species' relative abundance, were compared graphically (Magurran, 2004). For the Marina (MAR) fish assemblages' differences between jetties and channels were determined using the Student's $t$-test (Zar, 1998).

Species were also classified according to their frequency of occurrence in samples as frequent $(100-70 \%)$, common $(69-30 \%)$, occasional $(29-5 \%)$ and rare $(<5 \%)$.

When assumptions of normality and homoscedasticity (Levene's test) were met (Zar, 1998; Kochzius, 2002), analysis of variance (ANOVA) was used to evaluate spatial variations in fish densities at depth strata for 15 randomly-chosen censuses at each depth stratum. The Tukey (HSD) test was performed as a post-hoc test (Zar, 1998), when significant differences were observed. Even when ANOVA assumptions were not met, the non-parametric Kruskal-Wallis test (Zar, 1998) followed by the post-hoc Dunn test, when applicable, were applied.

The comparative analysis of fish communities among sampled areas included a cluster analysis (UPGMA) using the Bray-Curtis similarity coefficient for density values $\left(\right.$ fish $\left./ \mathrm{m}^{2}\right)$. The matrix included all the species that contributed with a minimum mean value of $0.02 \mathrm{fish} / \mathrm{m}^{2}$ in at least one area. Data were square root transformed to reduce the influence of the most abundant species.

Trophic classifications were based on Azevedo (1995), Harmelin-Vivien et al. (2001), Ferreira et al. (2004) and 
Froese \& Pauly (2009) and are proposed: herbivores (Hb) - fish that feed mostly on algae and include different behaviours such as territorial, browsing, and roving fishes; invertebrates feeders (In) - feed mostly on sessile and mobile invertebrates; carnivores (Ca) - feed mostly on fish, but also include invertebrates in their diet; planktivores ( $\mathrm{Pl})$ - includes day and night planktivores feeding on micro and macrozooplankton; and omnivores (Om) - feed on algae, detritus and small invertebrates.

\section{RESULTS}

A total of 52 species belonging to 45 genera and 26 families was observed (Table 1). From these, ten species were only included in the checklist and were not considered for any subsequent analyses, once they never occurred inside one of the $1034 \mathrm{om}^{2}$ transects, which accounted for 7209 fish. Common names can be assessed at the Department of

Table 1. Checklist of rocky reef fish from Azores Archipelago. Data for trophic category (TC) follows as Ca, carnivores; Hb, herbivores; In, invertebrate feeders; Om, omnivores; Pl, planktivores. Families are arranged according to Nelson (2006). Mean density values greater than 0.1 fish/ $\mathrm{m}^{2}$ are in boldface.

\begin{tabular}{|c|c|c|c|c|c|c|}
\hline Family & Species & TC & RA & FO & MD & $\pm \mathrm{SE}$ \\
\hline Dasyatidae & Dasyatis pastinaca (Linnaeus, 1758) & $\mathrm{Ca}$ & 0.01 & 0.98 & 0.000 & 0.02 \\
\hline Myliobatidae & Myliobatis aquila (Linnaeus, 1758) & $\mathrm{Ca}$ & & & & \\
\hline Congridae & Conger conger (Linnaeus, 1758) & $\mathrm{Ca}$ & & & & \\
\hline \multirow[t]{3}{*}{ Muraenidae } & Gymnothorax unicolor (Delaroche, 1809) & $\mathrm{Ca}$ & 0.04 & 2.94 & 0.001 & 0.02 \\
\hline & Muraena augusti (Kaup, 1856) & $\mathrm{Ca}$ & 0.08 & 5.88 & 0.001 & 0.02 \\
\hline & Muraena helena Linnaeus, 1758 & $\mathrm{Ca}$ & 0.06 & 2.94 & 0.001 & 0.02 \\
\hline Synodontidae & Synodus saurus (Linnaeus, 1758) & $\mathrm{Ca}$ & 0.42 & 5.88 & 0.007 & 0.06 \\
\hline \multirow[t]{2}{*}{ Phycidae } & Phycis phycis (Linnaeus, 1766) & $\mathrm{Ca}$ & 0.01 & 0.98 & 0.000 & 0.02 \\
\hline & Gaidropsarus guttatus (Collett, 189o) & $\mathrm{Ca}$ & & & & \\
\hline \multirow[t]{2}{*}{ Scorpaenidae } & Scorpaena maderensis Valenciennes, 1833 & $\mathrm{Ca}$ & 3.88 & 62.75 & 0.069 & 0.03 \\
\hline & Scorpaena notata Rafinesque, 1810 & $\mathrm{Ca}$ & & & & \\
\hline \multirow[t]{4}{*}{ Serranidae } & Epinephelus marginatus (Lowe, 1834) & $\mathrm{Ca}$ & 1.00 & 28.43 & 0.018 & 0.03 \\
\hline & Mycteroperca fusca (Lowe, 1838 ) & $\mathrm{Ca}$ & 0.01 & 0.98 & 0.000 & 0.02 \\
\hline & Serranus atricauda Günther, 1874 & $\mathrm{Ca}$ & 0.94 & 36.27 & 0.017 & 0.02 \\
\hline & Serranus cabrilla (Linnaeus, 1758) & $\mathrm{Ca}$ & & & & \\
\hline Apogonidae & Apogon imberbis (Linnaeus, 1758) & $\mathrm{Ca}$ & 0.07 & 3.92 & 0.001 & 0.02 \\
\hline Pomatomidae & Pomatomus saltatrix (Linnaeus, 1766) & $\mathrm{Ca}$ & & & & \\
\hline Mugilidae & Chelon labrosus (Risso, 1827) & $\mathrm{Om}$ & 6.78 & 24.51 & 0.120 & 0.11 \\
\hline Atherinidae & Atherina presbyter Cuvier, 1829 & $\mathrm{Pl}$ & & & & \\
\hline \multirow[t]{4}{*}{ Carangidae } & Pseudocaranx dentex (Bloch \& Schneider, 1801) & In & 0.33 & 5.88 & 0.006 & 0.04 \\
\hline & Seriola rivoliana Valenciennes, 1833 & $\mathrm{Ca}$ & 0.03 & 0.98 & 0.000 & 0.02 \\
\hline & Trachinotus ovatus (Linnaeus, 1758) & $\mathrm{Ca}$ & 0.31 & 6.86 & 0.005 & 0.03 \\
\hline & Trachurus picturatus (Bowdich, 1825) & $\mathrm{Pl}$ & 0.03 & 0.98 & 0.000 & 0.02 \\
\hline \multirow[t]{6}{*}{ Sparidae } & Boops boops (Linnaeus, 1758) & Om & 1.58 & 16.67 & 0.028 & 0.06 \\
\hline & Diplodus sargus (Linnaeus, 1758) & $\mathrm{Om}$ & 16.92 & 77.45 & 0.299 & 0.07 \\
\hline & Diplodus vulgaris (Geoffroy Saint-Hilaire, 1817) & Om & 0.12 & 3.92 & 0.002 & 0.02 \\
\hline & Pagellus acarne (Risso, 1827) & In & 13.04 & 32.35 & 0.230 & 0.12 \\
\hline & Pagrus pagrus (Linnaeus, 1758) & $\mathrm{Ca}$ & 1.04 & 18.63 & 0.018 & 0.04 \\
\hline & Sarpa salpa (Linnaeus, 1758) & $\mathrm{Hb}$ & 2.39 & 24.51 & 0.042 & 0.05 \\
\hline Mullidae & Mullus surmuletus Linnaeus, 1758 & In & 2.83 & 42.16 & 0.050 & 0.05 \\
\hline Kyphosidae & Kyphosus sectator (Linnaeus, 1758) & $\mathrm{Om}$ & 0.47 & 8.82 & 0.008 & 0.03 \\
\hline \multirow[t]{2}{*}{ Pomacentridae } & Abudefduf luridus (Cuvier, 1830) & $\mathrm{Om}$ & 1.90 & 45.10 & 0.034 & 0.03 \\
\hline & Chromis limbata (Valenciennes, 1833) & $\mathrm{Pl}$ & 3.62 & 21.57 & 0.064 & 0.11 \\
\hline \multirow[t]{6}{*}{ Labridae } & Centrolabrus caeruleus Azevedo, 1999 & In & 4.01 & 76.47 & 0.071 & 0.04 \\
\hline & Coris julis (Linnaeus, 1758) & In & 12.43 & 88.24 & 0.220 & 0.05 \\
\hline & Labrus bergylta Ascanius, 1767 & $\mathrm{Ca}$ & 0.25 & 16.67 & 0.004 & 0.02 \\
\hline & Symphodus mediterraneus (Linnaeus, 1758) & In & 0.17 & 5.88 & 0.003 & 0.02 \\
\hline & Thalassoma pavo (Linnaeus, 1758) & In & 11.89 & 91.18 & 0.210 & 0.04 \\
\hline & Xyrichthys novacula (Linnaeus, 1758) & In & & & & \\
\hline Scaridae & Sparisoma cretense (Linnaeus, 1758) & $\mathrm{Hb}$ & 1.73 & 28.43 & 0.031 & 0.07 \\
\hline Tripterygiidae & Tripterygion delaisi Cadenat \& Blache, 1970 & In & $7 \cdot 30$ & 66.67 & 0.129 & 0.06 \\
\hline \multirow[t]{5}{*}{ Blenniidae } & Lipophrys pholis (Linnaeus, 1758) & $\mathrm{Om}$ & & & & \\
\hline & Ophioblennius atlanticus (Valenciennes, 1836) & $\mathrm{Hb}$ & 0.33 & 7.84 & 0.006 & 0.03 \\
\hline & Parablennius incognitus (Bath, 1968) & Om & & & & \\
\hline & Parablennius parvicornis (Valenciennes, 1836) & Om & 0.32 & 2.94 & 0.006 & 0.05 \\
\hline & Parablennius ruber (Valenciennes, 1836) & $\mathrm{Om}$ & 0.37 & 18.63 & 0.007 & 0.02 \\
\hline \multirow[t]{2}{*}{ Gobiidae } & Gobius paganellus Linnaeus, 1758 & In & 0.80 & 30.39 & 0.014 & 0.02 \\
\hline & Pomatoschistus pictus (Malm, 1865) & In & 0.10 & 2.94 & 0.002 & 0.03 \\
\hline Sphyraenidae & Sphyraena viridensis Cuvier, 1829 & $\mathrm{Ca}$ & 0.08 & 2.94 & 0.001 & 0.02 \\
\hline Bothidae & Bothus podas (Delaroche, 1809) & $\mathrm{Ca}$ & 0.17 & 5.88 & 0.003 & 0.03 \\
\hline Balistidae & Balistes capriscus Gmelin, 1789 & In & 0.11 & 6.86 & 0.002 & 0.02 \\
\hline Tetraodontidae & Sphoeroides marmoratus (Lowe, 1838) & Om & 2.01 & 58.82 & 0.036 & 0.02 \\
\hline
\end{tabular}

RA, relative abundance; FO, frequency of occurrence; $\mathrm{MD}$, mean density $\left(\mathrm{fish} / \mathrm{m}^{2}\right) ; \pm \mathrm{SE}$, standard error. 
Oceanography and Fisheries from the University of Azores (www.horta.uac.pt).

The richest families were Sparidae (6 spp.), Labridae (5 spp.) and Carangidae (4 spp.), the most speciose genera being Parablennius, Muraena and Diplodus, with two species each. The ten most abundant species that consequently accounted for the highest densities were Diplodus sargus (Linnaeus, 1758), Pagellus acarne (Risso, 1827), Coris julis (Linnaeus, 1758), Thalassoma pavo (Linnaeus, 1758), Tripterygion delaisi Cadenat \& Blache, 1970, Chelon labrosus (Risso, 1827), Centrolabrus caeruleus Azevedo, 1999, Scorpaena maderensis Valenciennes, 1833, Chromis limbata (Valenciennes, 1833) and Mullus surmuletus Linnaeus, 1758 (Figure 2). Indeed, the ten most abundant fish corresponded to $82.7 \%$ of all fish counted during this study.

From the 42 species, $12 \%$ are epipelagic (Pseudocaranx dentex (Bloch \& Schneider, 1801); Seriola rivoliana Valenciennes, 1833; Trachinotus ovatus (Linnaeus, 1758); Trachurus picturatus (Bowdich, 1825) and Sphyraena viridensis Cuvier, 1829). The remaining 37 species are demersal $(57 \%)$ and benthic (31\%), strongly associated to the bottom.

\section{Trophic structure}

The majority (40\%) of the fish observed were carnivores (Ca), including 12 families with Serranidae and Muraenidae both with three species each and Carangidae with two species, as the richest ones. Invertebrate feeders (In), accounted for $26 \%$ of species, followed by omnivores (Om) with $21 \%$. The former included seven families, where Labridae was the richest ( 4 spp.) and the latter four families, being Sparidae (3 spp.) the richest one. Herbivores ( $\mathrm{Hb}$ ) accounted for $7 \%$ of the species and included three families, followed by planctivores (Pl) (5\%) with two families (Figure 3 ).

Observing the proportion of each trophic category at depth strata (Figure 4), the most abundant carnivore species at $2 \mathrm{~m}$, were Epinephelus marginatus (Lowe, 1834) and S. madeirensis (mean densities of 0.06 and $0.05 / \mathrm{m}^{2}$ ), while at $6 \mathrm{~m} \mathrm{~S}$. madeirensis and Serranus atricauda Günther, 1874 (mean densities of 0.06 and $0.02 / \mathrm{m}^{2}$ ), being $9 \mathrm{~m}$ and $14 \mathrm{~m}$ dominated by

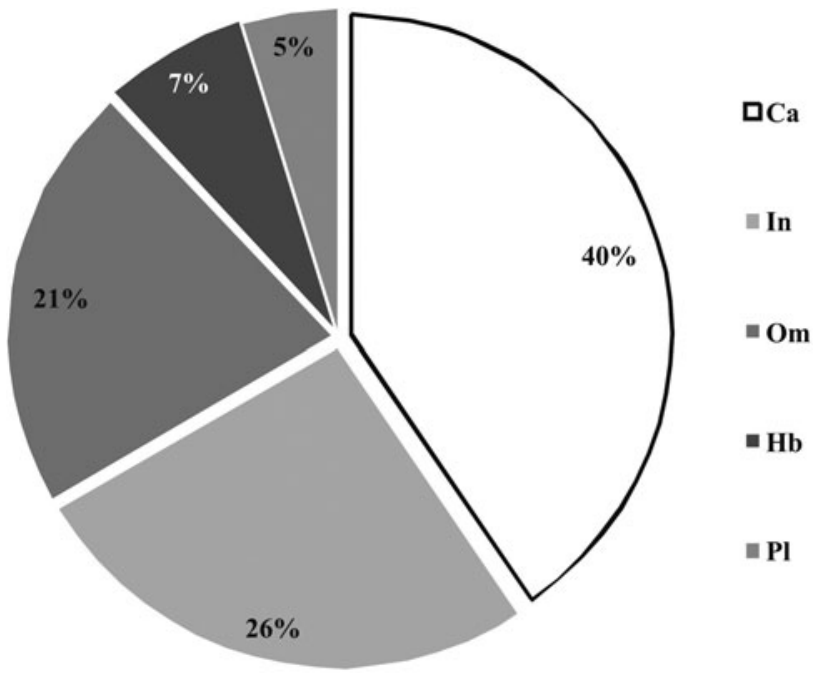

Fig. 3. Percentage of species in each trophic category of rocky reef fish recorded in the Azores.

S. madeirensis among carnivores (mean densities of 0.12 and $0.18 / \mathrm{m}^{2}$ respectively).

Among herbivores, although represented by only three species, the $6 \mathrm{~m}$ stratum concentrated the highest values of density for Sparisoma cretense (Linnaeus, 1758) $\left(0.11 / \mathrm{m}^{2}\right)$ and Sarpa salpa (Linnaeus, 1758) $\left(0.09 / \mathrm{m}^{2}\right)$, both present in all surveyed depth strata. Ophioblennius atlanticus (Valenciennes, 1836) occurred at the two shallowest strata being the most abundant at $2 \mathrm{~m}\left(0.03 / \mathrm{m}^{2}\right)$.

Despite this all omnivore species (except for Kyphosus sectator (Linnaeus, 1758), exclusively at $6 \mathrm{~m}$ ) were observed at the shallowest stratum $(\mathrm{N}=8)$, where $D$. $\operatorname{sargus}\left(0.36 / \mathrm{m}^{2}\right)$ and C. labrosus $\left(0.35 / \mathrm{m}^{2}\right)$ accounted for the highest mean densities; only five species were observed at the deepest stratum and with low densities, D. sargus $\left(0.09 / \mathrm{m}^{2}\right)$ and Abudefduf luridus (Cuvier, 1830) $\left(0.08 / \mathrm{m}^{2}\right)$.

The invertebrate feeders $C$. julis and T. pavo presented both the highest mean densities $\left(0.31 / \mathrm{m}^{2}\right.$ and $\left.0.26 / \mathrm{m}^{2}\right)$ considering

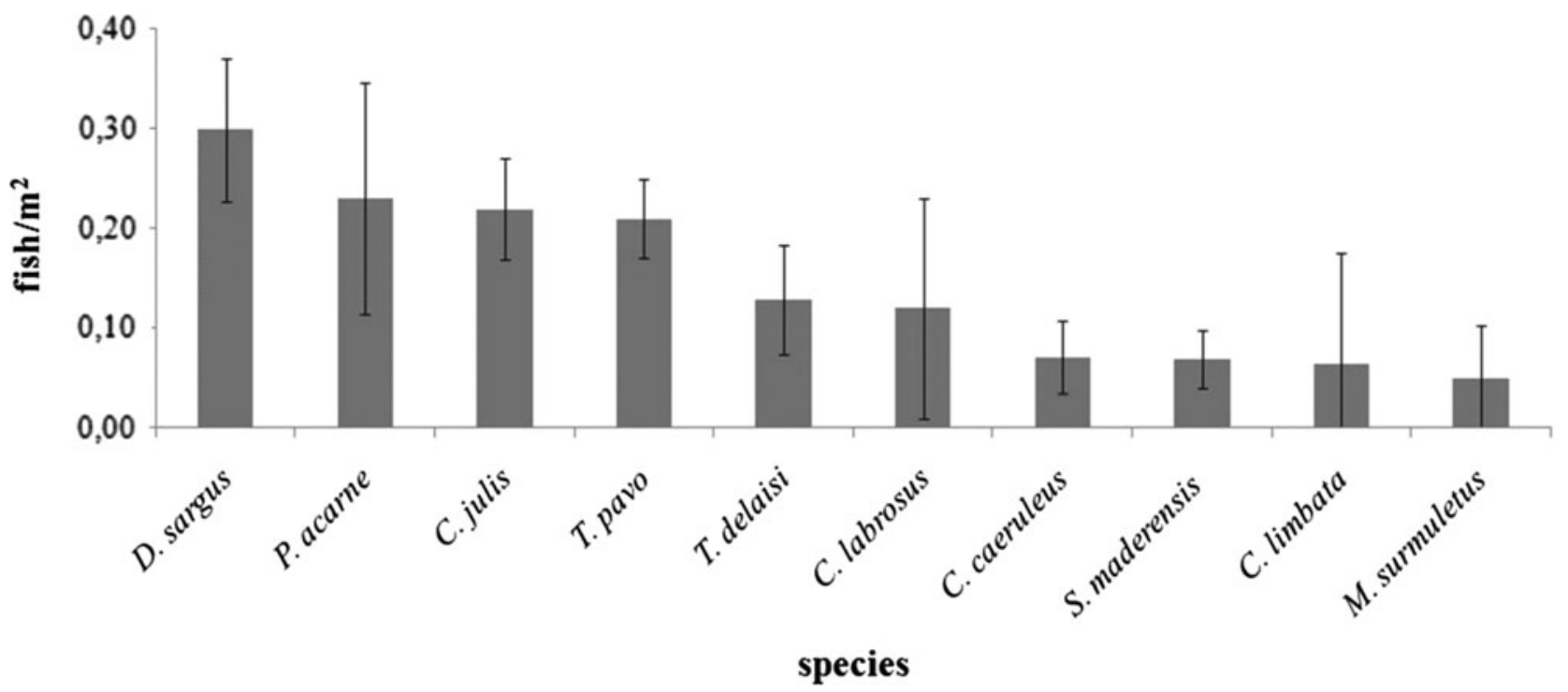

Fig. 2. Mean densities (fish $/ \mathrm{m}^{2}$ ) with respective standard error bars of the ten most abundant species. 


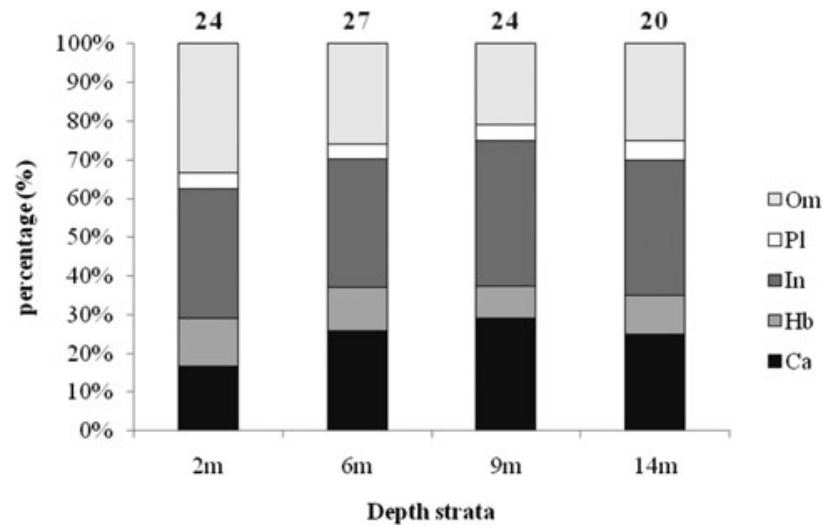

Fig. 4. Proportion of trophic categories among sampled depth strata. Bold numbers refer to richness.

all sampled depths. Tripterygion delaisi also presented important values $\left(0.13 / \mathrm{m}^{2}\right)$ at the shallowest stratum.

Planktivores were mostly represented by C. limbata $\left(0.36 / \mathrm{m}^{2}\right.$ at $\left.14 \mathrm{~m}\right)$, which was not observed only at the shallowest stratum, where $T$. picturatus was observed, although in very low densities $\left(0.003 / \mathrm{m}^{2}\right)$.

\section{Reef-fish frequency, abundance and distribution along depth strata}

Regarding species frequency of occurrence, four species (the invertebrate feeders T. pavo, C. julis and C. caeruleus and the omnivorous $D$. sargus) were considered frequent, eight common (three carnivorous, three invertebrate feeders and two omnivorous), 18 occasional $(29-5 \%)$ and 12 rare $(<5 \%)$ (Table 1$)$.

Abundant species presented a wide variation in densities regarding the sampled depths, and three groups were observed: group (A) of species that had a preference for shallower areas; group (B) of species that had a preference for deeper areas; and group (C) of species that had no clear preference for any depth strata.

Group (A) (Figure 5) was formed by three species: C. caeruleus (Figure $11 \mathrm{~A}$ ), did not show a clear distribution pattern, but data suggest a preference for shallower areas $(2,6$ and $9 \mathrm{~m}$ depth concentrates $92.3 \%$ of observations); significant differences on densities were observed only for the $14 \mathrm{~m}$ $\left(\mathrm{F}_{(3,56)}=3.096 P<0.05\right)$. On the other, although no significant differences were observed for D. sargus (Figure 11D) $\left(\mathrm{F}_{(3,56)}=2.438 \quad P=0.074\right)$ and $P$. acarne (Figure $11 \mathrm{E}$ ) $\left(\mathrm{H}_{(3,60)}=5.209 P=0.157\right)$, they had a tendency to be negatively distributed along depth strata.

Group (B) (Figure 6) was formed by four species: S. maderensis (Figure $11 \mathrm{~B}$ ), presented a positive relationship for density regarding depth strata. Significant differences formed three groups $\left(\mathrm{F}_{(3,56)}=13.516 \mathrm{P}<0.01\right)$, but both shallower strata differed from the deepest, and since no significant differences were detected between 9 and $14 \mathrm{~m}$ (that represents more than $70 \%$ of observations), S. maderensis shows a clear preference for deeper areas on rocky reefs, as C. limbata (Figure 11I) does. This species was not even observed in the shallowest stratum, and concentrated $83 \%$ of observations in the deepest strata $\left(\mathrm{H}_{(2,45)}=22.99 P<0.01\right)$.

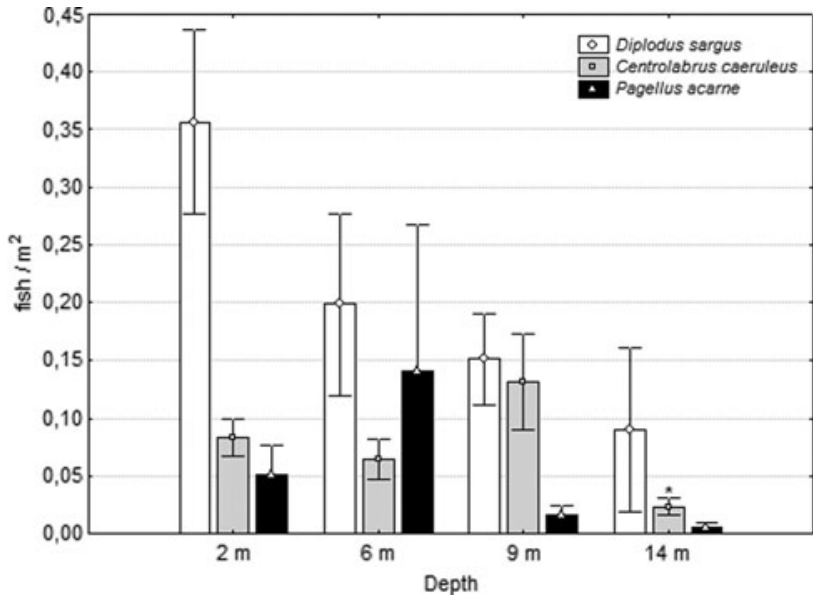

Fig. 5. Densities (mean $\pm \mathrm{SE}$ ) of group A: Diplodus sargus, Centrolabrus caeruleus and Pagellus acarne among depth strata. *denotes significant differences for species within strata.

A very similar distribution was observed for the small grouper S. atricauda (Figure $11 \mathrm{C}$ ), which presented the same tendency, but in this case, where no specimens were observed in the shallowest stratum, significant differences at $P<0.05$ level $\left(\mathrm{F}_{(2,42)}=3.79\right)$ were detected between the group formed by 6 and $9 \mathrm{~m}$, and the deepest stratum, that concentrated almost half (48\%) of observations. Although this carnivorous species was not abundant, it was frequent in more than one-third of the samples.

The wrasse C. julis (Figure $11 \mathrm{~K}, \mathrm{~L}$ ), almost showed significant differences $\left(\mathrm{F}_{(3,56)}=2.7819 P=0.0429\right)$ among depth strata, but no differences were observed in the post-hoc test. Anyway, a clear preference for deeper areas is evident.

Group (C) (Figure 7) was formed by three species: T. pavo (Figure $11 \mathrm{~F})$ was the most evenly distributed species $\left(\mathrm{F}_{(3,56)}=\right.$ $0.108 P=0.955$ ); followed by $T$. delaisi (Figure $11 \mathrm{H}$ ) $\left(\mathrm{H}_{(3,60)}=3.92 P=0.27\right)$. Although not so abundant, S. marmoratus (Figure $11 \mathrm{G}$ ) was a common species, present in $58 \%$ of the samples, but it was rarely observed at the shallowest stratum, which differed significantly from the others $\left(\mathrm{H}_{(3,60)}=22.84 P<0.01\right)$.

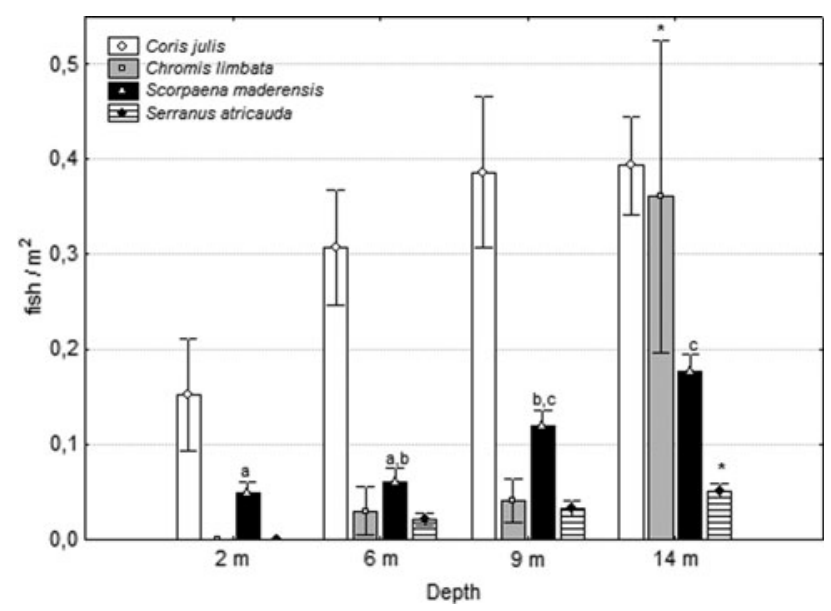

Fig. 6. Densities (mean $\pm \mathrm{SE}$ ) of group B: Coris julis, Chromis limbata, Scorpaena maderensis and Serranus atricauda among depth strata. *denotes significant differences for species within strata. Letters show groups detected by post-hoc tests. 


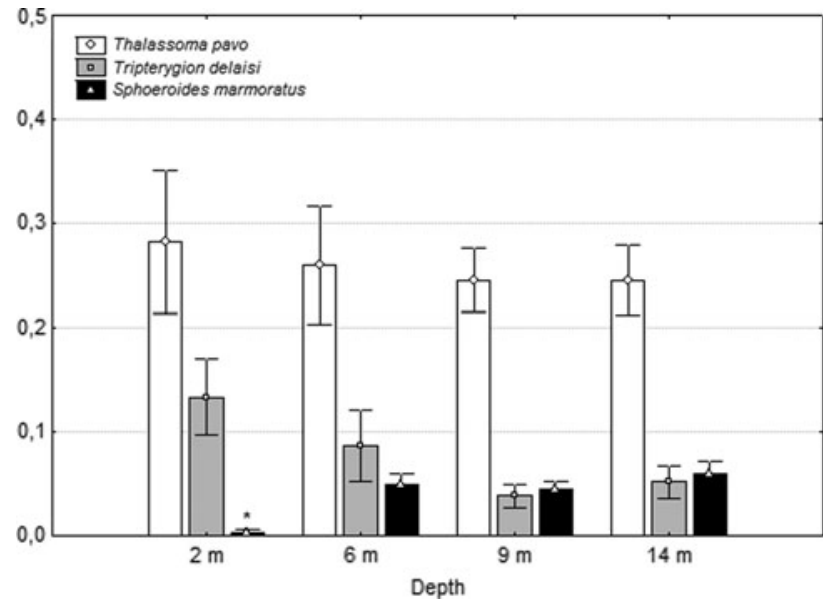

Fig. 7. Densities (mean \pm SE) of group C: Thalassoma pavo, Trypterygion delaisi and Sphoeroides marmoratus among depth strata. *denotes significant differences for species within strata.

Although no significant differences were observed among depth strata for the indices calculated (Table 2), the highest value of mean density $\left(1.8 \mathrm{fish} / \mathrm{m}^{2}\right)$ and mean richness (10.07) were associated to the shallowest stratum $(2 \mathrm{~m})$, and the lowest $\left(1.3 \mathrm{fish} / \mathrm{m}^{2}\right.$ and 9.73$)$ to the $9 \mathrm{~m}$ depth. The highest diversity values, as well as evenness, were associated to the deeper strata ( 9 and $14 \mathrm{~m}$ ).

\section{Reef-fish indices and distribution in sampled areas}

Mean richness was quite similar among areas, with an overall mean value of 9.8 species, being the lowest value associated to SAL (4) and the highest to Gruta das Agulhas (GRA) (16). Mean abundances had a great variation, from $45.4 \mathrm{fish} / 40 \mathrm{~m}^{2}$ at Salguiros (SAL) to $86.9 \mathrm{fish} / 40 \mathrm{~m}^{2}$ at MAR, and mean overall value of $68.2 \mathrm{fish} / 40 \mathrm{~m}^{2}$. Diversity index ranged from 1.6 at SAL to 1.9 at Baía das Pombas (BA) and 1.87 as a mean value. On the other hand, evenness ranged from 0.72 at MAR to 0.83 at Ilhéudas Cabras (ICA), with mean values of 0.79. The total absolute number of fish $/ 4 \mathrm{om}^{2}$ also had a great variation, from 17 at SAL to 207 at MAR. These extreme values at MAR were due to the presence of huge schools of young $P$. acarne, D. sargus and C. labrosus, that alone accounted for $69.5 \%$ of total abundance.

Once the Marina (MAR) was the unique area with highly anthropogenic influence, samplings were obtained under the jetties and channels (between jetties). Comparisons of communities between the two sampled areas, showed that no significant differences were observed $(\mathrm{df}=46 ; t=0.0363, P=$ 0.971). Mean densities for the five most abundant species also did not show significant differences, except for the

Table 2. ANOVA results of comparisons among depth strata.

\begin{tabular}{lll}
\hline & $\mathbf{F}_{(3,56)}$ & $P$ \\
\hline$S$ & 0.06 & 0.9805 \\
Density & 1.01 & 0.3927 \\
Diversity $\left(\mathrm{H}^{\prime}\right)$ & 0.84 & 0.4737 \\
Evenness $\left(\mathrm{J}^{\prime}\right)$ & 1.33 & 0.2719 \\
\hline
\end{tabular}

S, richness; density, $\left(\right.$ fish $\left./ 40 \mathrm{~m}^{2}\right)$; $\mathrm{H}^{\prime}$, Shannon-Wiener; $J^{\prime}$, Pielou.

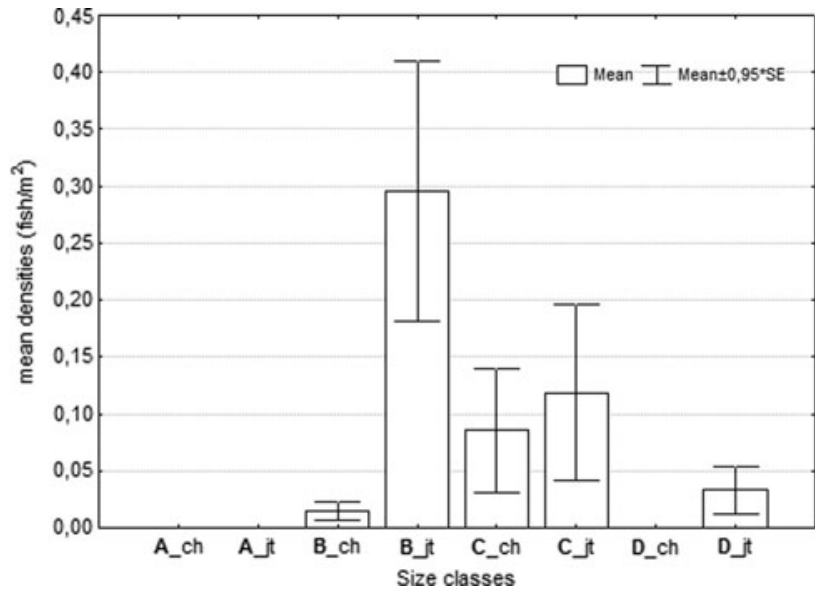

Fig. 8. Densities (mean $\pm \mathrm{SE}$ ) of Chelon labrosus sampled on channels (ch) and jetties (jt) at the Marina, with respective standard error bars (SE). Size-classes: (A) $<10 \mathrm{~cm}$; (B) $11-20 \mathrm{~cm}$; (C) $21-30 \mathrm{~cm}$; (D) $>31 \mathrm{~cm}$.

thicklip grey mullet, C. labrosus (Figure 11J), which was observed in significantly higher densities under the jetties $(\mathrm{df}=22 ; t=2.406, P<0.05)$ (Figure 8$)$.

The representative cluster of mean densities (Figure 9) showed two main groups: (a) composed of MAR, COR and Biscoitos (BIS) areas; and (b) composed by ICA, Cinco Ribeiras (CIR), GRA and BAP; being SAL in a single isolated link. The dominance-diversity curves are presented in Figure 10.

\section{DISCUSSIDN}

Communities of fish sampled had a dominance of few species, T. pavo, C. julis, D. sargus and C. caeruleus being the most frequent, and a high percentage of rare species (Table 1) was observed. The five epipelagic species were commonly observed in a strong association within the rocky bottom areas sampled.

Similarly to our results, Bortone et al. (1994), employing stationary census methodology identified 37 species along the rocky shores of the Canary Islands, and Hajagos \& Van Tessell (2001), also reported similar results: 48 species, grouped in 29 families in 211 stationary censuses in the

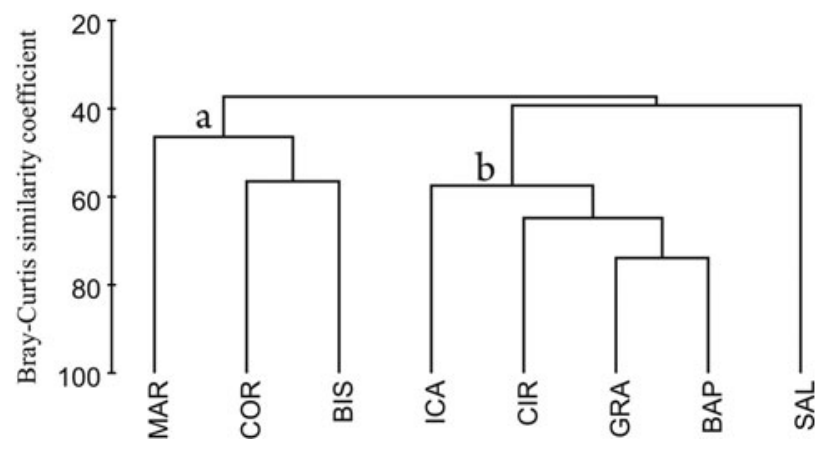

Fig. 9. Cluster analysis (Bray-Curtis similarity coefficient, UPGMA for density values $\left(\mathrm{fish} / \mathrm{m}^{2}\right)$ ). COR, Corvo; BIS, Biscoito; BAP, Baía das Pombas; CIR, Cinco Ribeiras; MAR, Marina; ICA, Ilhéu das Cabras; GRA, Gruta das Agulhas; SAL, Salgueiros. 

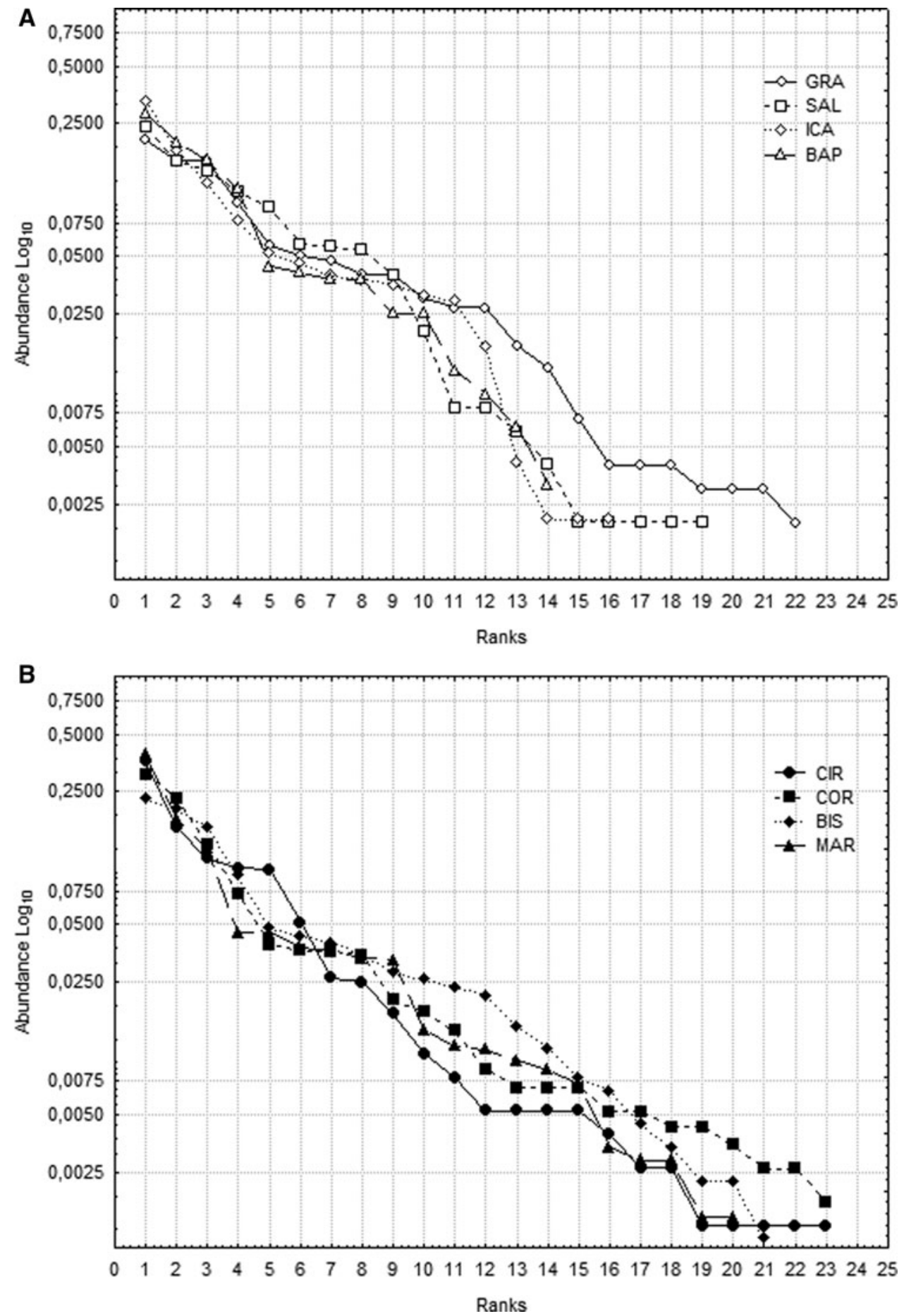

Fig. 1o. Dominance-diversity curves for each area. (A) GRA, Gruta das Agulhas; SAL, Salgueiros; ICA, Ilhéu das Cabras; BAP, Baía das Pombas; (B) CIR, Cinco Ribeiras; COR, Corvo; BIS, Biscoitos; MAR, Marina.

Canary Islands. On the other hand, Harmelin-Vivien et al. (2001), in one of the first attempts of underwater visual censuses in the Azores, surveyed five Azorean islands (which did not include Terceira or Corvo) during the Bio-Oceanographic survey in 1979, identifying 57 species, in depths up to $25 \mathrm{~m}$, employing the circular point method (Harmelin-Vivien et al., 1985).

Our study showed Sparidae and Labridae families as the ones with most abundant species, but Harmelin-Vivien et al. (2001) also included Carangidae and Pomacentridae in their study.
Bleniids have been considered the most conspicuous species from shallow intertidal rocky environments (see references in Santos et al., 1997), but although P. ruber and $O$. atlanticus were considered occasional in our samples, shallow environments were clearly dominated by labrids (T. pavo and C. julis), sparids (D. sargus) and tripterygids (T. delaisi). On the other hand, deeper strata were represented by the same labrids, and the pomacentrid C. limbata.

Among carnivores, the scorpaenid S. madeirensis was the most abundant and frequent species, with densities increasing 
A

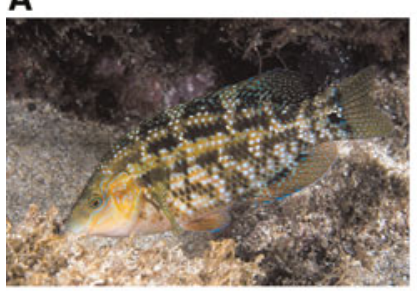

E

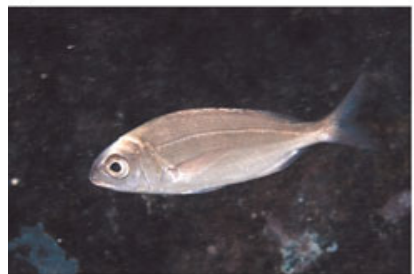

I

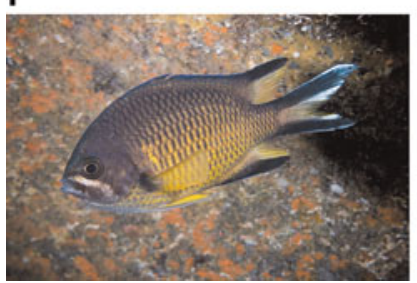

B

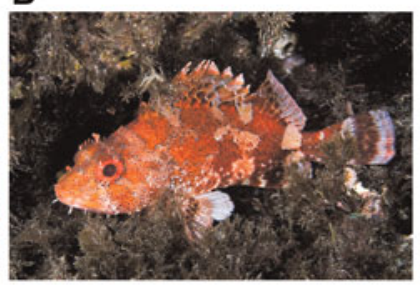

$\mathbf{F}$

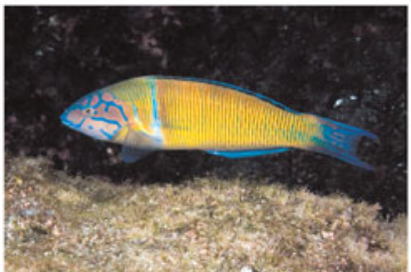

J

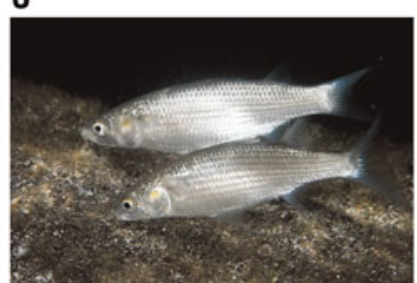

C

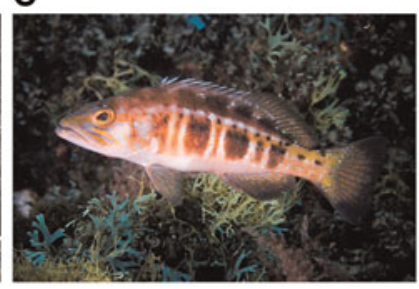

G

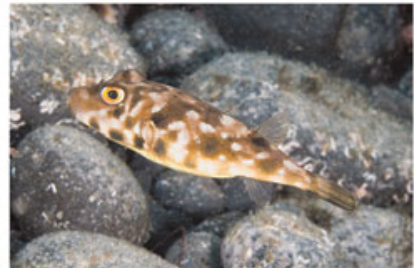

K

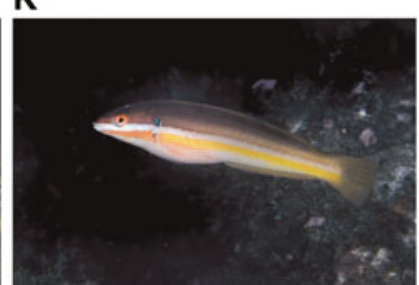

D

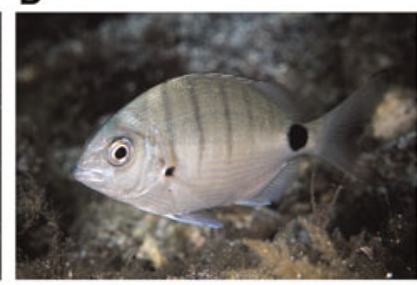

H

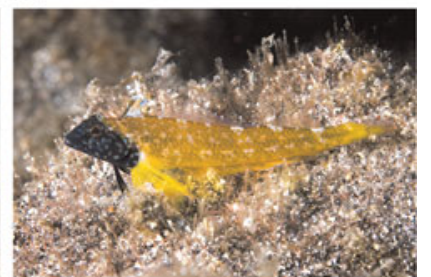

$\mathbf{L}$

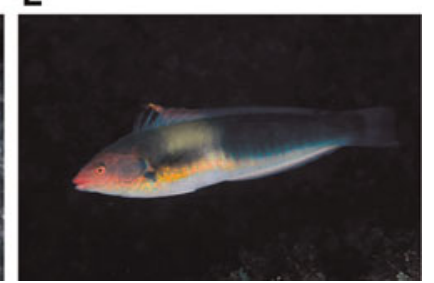

Fig. 11. (A) Centrolabrus caeruleus; (B) Scorpaena maderensis; (C) Serranus atricauda; (D) Diplodus sargus; (E) Pagellus acarne; (F) Thalassoma pavo; (G) Sphoeroides marmoratus; (H) Tripterygion delaisi; (I) Chromis limbata; (J) Chelon labrosus; (K) Coris julis-initial female; (L) C. julis-terminal male. Photographs by A.A. Bertoncini.

with depth. Although the majority (40\%) of the fish observed were carnivores, the proportion of trophic categories remained similar between the depth strata (Figure 4) (very similar to the results of Harmelin-Vivien et al., 2001). These substantial differences revealed that at each depth stratum trophic categories were represented by different species of the same trophic group, especially for the carnivore ones, which accounted for $66.6 \%$ of rare species. Among them, T. ovatus and Muraena helena Linnaeus, 1758 occurred only at the $2 \mathrm{~m}$ stratum; Bothus podas (Delaroche, 1809) and Synodus saurus (Linnaeus, 1758), were exclusively present at the $6 \mathrm{~m}$ stratum, the latter known as a shallow-water predator of post-larval and juvenile of S. viridensis (Barreiros et al., 2008). On the other hand, Dasyatis pastinaca (Linnaeus, 1758) and Phycis phycis (Linnaeus, 1766) were exclusively observed at the $9 \mathrm{~m}$ stratum. All invertebrate feeders, except for $P$. dentex (restricted to the $6 \mathrm{~m}$ stratum), were present at $9 \mathrm{~m}$, and although $2 \mathrm{~m}$ and $6 \mathrm{~m}$ presented the same proportion of invertebrate feeders, Symphodus mediterraneus (Linnaeus, 1758) at $2 \mathrm{~m}$, was substituted by M. surmuletus at $6 \mathrm{~m}$, especially common along rocky-sand interface at SAL.

The hovering herbivore $S$. cretense, the unique Scaridae species in the Azores, and the sparid S. salpa revealed the highest mean densities at $6 \mathrm{~m}\left(0.11 / \mathrm{m}^{2}\right.$ and $\left.0.09 / \mathrm{m}^{2}\right)$ among herbivores. Sarpa salpa was commonly observed in small schools of up to 25 individuals, and scarids sampled in small groups of up to five individuals, but once summer is the breeding season for $S$. cretense, this value was biased due to a single sample where a mating school of 51 individuals crossed the transect line. Scarids are generally shy and get easily scared in the presence of divers, being easily underestimated (although often observed nearby transects, frequency of occurrence was less than $30 \%$ inside transects), when methodologies do not focus this fish group (wider transects would be more applicable).

Large individuals of the dusky grouper E. marginatus were not observed in any depth strata, whereas Harmelin-Vivien et al. (2001) in 1979 observed these in deeper strata on other Azorean islands. Inversely, juveniles of E. marginatus were observed in shallow habitat, as tidal pools, from postlarvae until reaching approximately $45 \mathrm{~cm}$ total length (see Azevedo et al., 1995; Machado et al., in preparation). The dominance-diversity curves (Figure 10) emphasize that species were not evenly distributed within sampled rocky shore areas and a dominance can be observed, especially in MAR and CIR, which presented a steeper slope shape, despite an elevated richness for both areas (more than half the total number of species). MAR was dominated by numerous schools of $P$. acarne of small size, which were far more responsible for the highest values of density in this study $\left(2.0 / \mathrm{m}^{2}\right)$ and represented $38.9 \%$ of relative abundance, followed by $D$. sargus (17.9\%) and C. labrosus (12.6\%). CIR was dominated by C. julis (35.7\%), T. pavo (16.2\%) and P. acarne (11.1\%). Although M. surmuletus and C. julis were the most abundant species at SAL, no clear dominance was observed. However, C. julis, was the dominant species not only at CIR (37.5\%), but BAP (28.4\%) and GRA (20.3\%), in all the cases followed by T. pavo.

Among the species which occupied a position in the first three ranks considering the eight areas, T. pavo had six occurrences, but was never the most abundant, $C$. julis five and $D$. sargus four occurrences. Diplodus sargus dominated only at COR, followed by $T$. delaisi; BIS was dominated by C. labrosus, and ICA by C. limbata.

The lower values associated to SAL for richness, mean abundance and diversity were probably due to the fact that 
this was the steepest rocky shore, shallow $(8 \mathrm{~m})$ and sandy bottom was close, which contributed to the high densities of M. surmuletus. Although SAL was sampled only at $6 \mathrm{~m}$ stratum, we discard any influence of depth, since an overall analysis of mean species number at the four sampled depth strata $(2,6,9$ and $14 \mathrm{~m})$ showed an incredible similarity of mean richness of 9.8 species at each strata.

Figure 8 shows how juveniles $(11-20 \mathrm{~cm}$ size-class) of thicklip grey mullet contributed to the highest mean densities of C. labrosus under the jetties. Two main factors contributed to differences: first, densities were composed mostly of juveniles, and second, floating jetties provide shadow, which is used by C. labrosus schools to hide.

Cluster analyses grouped MAR, COR and BIS, which were not only the shallowest areas, but enclosed and protected from waves' action. BAP, GRA, COR and ICA, had the highest values for diversity, which was accompanied by high values of evenness and expressive richness. On the other hand, MAR, CIR and BIS, had low values for evenness, as a result of the dominance of $P$. acarne, D. sargus and C. labrosus at MAR, C. julis and T. pavo at CIR, and C. labrosus, D. sargus and T. pavo at BIS.

This assessment shows that the Azorean ichthyofauna of shallow rocky reefs is relatively rich and diverse when compared to other oceanic archipelagos (Canary Islands). Ecological interactions are still poorly studied. Despite our sampling limitations, results show patterns of abundance, diversity and distribution along studied depth gradients. Long-term studies should also be conducted to investigate ecological relationships, refine patterns observed inside and outside tidal pools, explore deeper areas, as well as monitor exotic species presence, such as Diplodus vulgaris (Geoffroy Saint-Hilaire, 1817) on shallow rocky reefs.

\section{ACKNDWLEDGEMENTS}

The authors would like to thank Centro Náutico Aquarius, through the agreement with Universidade dos Açores, Dr Alfredo Emílio Silveira de Borba, for University of Azores facilities at Terceira island, Nauticorvo staff and Paulo Santos for SCUBA tanks. A.A.B. benefited from a Brazilian PhD Grant (CNPq 210231/2006-8).

\section{REFERENCES}

Afonso P. (2002) Spatial patterns in the littoral fish community of the Azores. MSc thesis. University of Coimbra, Coimbra, Portugal, 104 pp.

Afonso P. (2007) Habitat use and movement patterns of three sympatric fishes with different life history strategies: implications for design of marine reserves. PhD thesis. University of Hawaii, USA, 202 pp.

Afonso P., Fontes J., Holland K.N. and Santos R.S. (2009) Multi-scale patterns of habitat use in a highly mobile reef fish, the white trevally Pseudocaranx dentex, and their implications for marine reserve design. Marine Ecology Progress Series 381, 273-286.

Azevedo J.M.N. (1995) Food web of the Azorean shallow water marine ichthyological communities: a guild approach. Boletim do Museu Municipal do Funchal Supplement 4, 29-53.

Azevedo J.M.N., Rodrigues J.B., Mendizabal M. and Arruda L.M. (1995) Study of a sample of dusky groupers, Epinephelus marginatus
(Lowe, 1834), caught in a tide pool at Lajes do Pico, Azores. Boletim do Museu Municipal do Funchal Supplement 4, 55-64.

Azevedo J. (1997) Estrutura de uma comunidade ictiológica do litoral da Ilha de São Miguel (Açores): caracterização e variações espaçotemporais. PhD thesis. Universidade dos Açores, Ponta Delgada.

Azevedo J.M.N., Cepeda H.I.R. and Rodrigues J.B. (1999) Notes on the biology of Centrolabrus caeruleus Azevedo, 1999 (Teleostei: Labridae). Arquipélago Life and Marine Sciences 17, 27-36.

Barreiros J.P. (1995) Aspectos do Comportamento e da Reprodução do Mero Epinephelus marginatus (Lowe, 1834) nos Açores. Provas de Aptidão Pedagógica e Capacidade Científica, Departamento de Ciências Agrárias, Universidade dos Açores, 95 pp.

Barreiros J.P. and Santos R.S. (1998) Notes on the food habits and predatory behaviour of the dusky grouper, Epinephelus marginatus (Lowe, 1834) (Pisces: Serranidae) in the Azores. Arquipélago Life and Marine Sciences 16A, 29-35.

Barreiros J.P., Santos R.S. and Borba E.A. (2002) Food habits, schooling and predatory behaviour of the yellowmouth barracuda, Sphyraena viridensis Cuvier, 1829 (Perciformes: Sphyraenidae) in the Azores. Cybium-International Journal of Ichthyology 26, 83-88.

Barreiros J.P., Cardigos F., Soares M.S.C. and Machado L.F. (2008) Juvenile Sphyraena viridensis, preyed by the lizard fish Synodus saurus, a new predatory association from the Azores (NE Atlantic Ocean). Cybium-International Journal of Ichthyology 32, 273-274.

Bertoncini A.A., Machado L.F., Barreiros J.P., Hostim-Silva M. and Verani J.R. (2009) Cleaning activity among Labridae in the Azores: the rainbow wrasse Coris julis and the Azorean blue wrasse Centrolabrus caeruleus. Journal of the Marine Biological Association of the United Kingdom 89, 859-861.

Bortone S.A., Van Tassell J.L., Brito A., Falcon J.M., Menia J. and Bundrick C.M. (1994) Enhancement of the nearshore fish assemblage in the Canary Islands with artificial habitats. Bulletin of Marine Science $55,602-608$.

Brock V.E. (1954) A preliminary report on a method of estimating reef fish populations. Journal of Wildlife Management 18, 297-308.

Edgar G.J., Barrett N.S. and Morton A.J. (2004) Biases associated with the use of underwater visual census techniques to quantify the density and size-structure of fish populations. Journal of Experimental Marine Biology and Ecology 308, 269-290.

Ferreira C.E.L., Floeter S.R., Gasparini J.L., Joyeux J.C. and Ferreira B.P. (2004) Trophic structure patterns of Brazilian reef fishes: a latitudinal comparison. Journal of Biogeography 31, 1093-1106.

Figueiredo M., Morato T., Barreiros J.P., Afonso P. and Santos R.S. (2005) Feeding ecology of the white seabream, Diplodus sargus, and the ballan wrasse, Labrus bergylta, in the Azores. Fisheries Research 75, $107-119$.

França Z., Cruz J.V., Nunes J.C. and Forjaz V.H. (2003) Geologia dos Açores: uma perspectiva actual. Açoreana 10, 11-140.

Froese R. and Pauly D. (2009) FishBase. Available online at: http://www. fishbase.org (Accessed: 13 August 2009.)

Hajagos J.G. and Van Tassell J.L. (2001) A visual survey of the inshore fish communities of Gran Canaria (Canary Islands). Arquipélago Life and Marine Sciences 18A, 97-106.

Harmelin-Vivien M.L., Harmelin J.-G., Chauvet C., Duval C., Galzin R., Lejeune P., Barnabe G., Blanc F., Chevalier R., Duclerc J. and Lasserre G. (1985) Evaluation visuelle des peuplements et populations de poissons: méthodes et problèmes. Revue d'Ecologie (Terre Vie) 40, 467-539. 
Harmelin-Vivien M.L., Harmelin J.-G. and Almeida A.J. (2001) Structure of fish assemblages on coastal rocky shores of the Azores. Boletim do Museu Municipal do Funchal Supplement 6, 127-138.

Kochzius M. (2002) Ecology, genetic population structure, and molecular phylogeny of fishes on coral reefs on the Gulf of Aqaba and northern Red Sea. PhD thesis. University of Bremen, Bremen, Germany, 156 pp.

Kulbicki M. (1998) How the acquired behaviour of commercial reef fishes may influence the results obtained from visual censuses. Journal of Experimental Marine Biology and Ecology 222, 11-30.

Magurran A.E. (2004) Measuring biological diversity. Oxford: Blackwell Science, viii $+256 \mathrm{pp}$.

Morato T., Santos R.S. and Andrade J.P. (2000) Feeding habits, seasona and ontogenic shift of blacktail comber, Serranus atricauda (Pisces: Serranidae), from the Azores, north-eastern Atlantic. Fisheries Research 49, 51-59.

Morato T.P., Afonso P., Lourinho P., Barreiros J.P., Santos R.S. and Nash R.D.M. (2001) Length-weight relationships for 21 coastal fish species of the Azores, north-eastern Atlantic. Fisheries Research 50 297-302.

Morton B., Britton J.C. and Martins A.M.F. (1998) Costal ecology of the Azores. Ponta Delgada, Portugal: Sociedade Afonso Chaves, VIII + $249 \mathrm{pp}$.

Nash R.D.M. and Santos R.S. (1993) The occurrence of the lesser weeve (Echiichthys vipera) (Cuvier 1829) in the Azores. Journal of Fish Biology 43, 317-319.

Nelson J.S. (2006) Fishes of the world. 3rd edition. New York: John Wiley \& Sons, Inc, $624 \mathrm{pp}$.

Patzner R.A., Santos R.S., Ré P. and Nash R.D.M. (1992) Littoral fishes of the Azores: an annotated checklist of fishes observed During the "Expedition Azores 1989". Arquipélago Life and Earth Sciences 10, $101-111$.

Patzner R.A. and Santos R.S. (1993) Ecology of littoral fishes of the Azores. Courier Forschungsinstitut Senckenberg 159, 423-427.

Porteiro F.M., Barreiros J.P. and Santos R.S. (1996) Wrasses (Teleostei: Labridae) of the Azores. Arquipélago-Life and Marine Sciences 14, $23-40$.
Porteiro F.M., Santos R.S., Gonçalves J.M., Menezes G.M. and Fonseca L.C. (1998) Ichthyofauna of lagoa de Santo Cristo-São Jorge Island, Azores. Açoreana 8, 447-456.

Ré P. (1990) Ecologia dos peixes litorais. p. 129-150. In Expedição Açores 89: Ecologia e taxonomia do litoral marinho dos Açores. Relatório preliminar. Parte I, Vols. 1 e 2. DOP Technical Report, University of the Azores, Portugal, pp. 129-150.

Santos R.S., Nash R.D.M. and Hawkins S.J. (1994) Fish assemblages on intertidal shores of the Island of Faial, Azores. Arquipélag-Life and Marine Sciences 12A, 87-100.

Santos R.S. (1995) Allopaternal care in the redlip blenny. Journal of Fish Biology 47, 350-353.

Santos R.S., Hawkins S., Monteiro L.R., Alves M. and Isidro E.J. (1995) Marine research, resources and conservation in the Azores. Aquatic Conservation: Marine and Freshwater Ecosystems 5, 311-354.

Santos R.S., Porteiro F.M. and Barreiros J.P. (1997) Marine fishes of the Azores: Annotated checklist and bibliography. Arquipélago-Life and Marine Sciences Supplement 1, XXII + 231 pp.

Soares M.S.C., Barreiros J.P., Sousa L. and Santos R.S. (2002) Agonistic and predatory behaviour of the lizardfish Synodus saurus (Linnaeus, 1758) (Actinopterygii: Synodontidae) from the Azores. AquaJournal of Ichthyology and Aquatic Biology 6, 53-6o.

Sousa L., Barreiros J.P., Soares M.S.C., Hostim-Silva M. and Santos R.S. (2003) Preliminary notes on the reproductive biology of the lizardfish, Synodus saurus (Actynopterygii: Synodontidae) in the Azores. Cybium-International Journal of Ichthyology 27, 41-45.

and

Zar H.J. (1998) Biostatistical analysis. 4th edition. Upper Saddle River, NJ: Prentice-Hall.

\section{Correspondence should be addressed to:}

Á.A. Bertoncini

Universidade Federal de São Carlos--PPGERN_CxP.676

São Carlos SP 13.565-905 Brazil

email: athilapeixe@gmail.com 